\title{
Knowledge, Attitudes and Practices of the Health Personnel of the Pediatric and Gynecology-Obstetrics Departments of the Bouaké University Hospital Center (CHU) regarding the Intestinal Microbiota and the First 1000 Days of Life
}

\author{
Azagoh-Kouadio Richard1*, Yao Kouassi Christian², Aka-Tanoh Aude Hélène², \\ Siallou-Avi Christelle ${ }^{2}$, Yeboua Kossonou Roland ${ }^{2}$, Gnantin Josette Landryse Sahi'2, \\ Adou Léioh Roméoº ${ }^{2}$ Akanji Iburaima ${ }^{2}$, Amani Alexise ${ }^{2}$, Asse Kouadio Vincent ${ }^{2}$ \\ ${ }^{1}$ Pediatrics Department of the University Hospital Center of Angré, Abidjan, Côte d'Ivoire \\ ${ }^{2}$ Pediatrics Department of the University Hospital Center of Bouaké, Bouaké, Côte d'Ivoire \\ Email: *azagoh.richard@gmail.com, yaokc777@gmail.com, audeaka@gmail.com, avichristelle611@gmail.com, \\ rolandyeboua13@gmail.com, firstsahi@yahoo.com, leioh91@hotmail.fr, ibrahimakanji@gmail.com, \\ amanialexise91@gmail.com, assevinc2014@gmail.com
}

How to cite this paper: Richard, A.-K., Christian, Y.K., Hélène, A.-T.A., Christelle, S.-A., Roland, Y.K., Sahi, G.J.L., Roméo, A.L., Iburaima, A., Alexise, A. and Vincent, A.K. (2021) Knowledge, Attitudes and Practices of the Health Personnel of the Pediatric and Gynecology-Obstetrics Departments of the Bouake University Hospital Center (CHU) regarding the Intestinal Microbiota and the First 1000 Days of Life. Open Journal of Pediatrics, 11, 19-34.

https://doi.org/10.4236/ojped.2021.111003

Received: December 31, 2020

Accepted: February 6, 2021

Published: February 9, 2021

\section{Abstract}

Introduction: The harmonious development of the intestinal microbiota during the first 1000 days of life promotes the child's immediate and future good health. The objective of the study was to evaluate the knowledge and practices of health personnel on the intestinal microbiota and the first 1000 days of life for the improvement of child health. Methods: Knowledge, attitudes and practices (KAP) type survey conducted among health personnel of the pediatric and gynecology-obstetrics departments of the Bouaké University Hospital from July 1 to 31,2017 . All consenting agents working in the said services and present at the time of the study were included. The parameters studied concerned socio-professional characteristics, knowledge of the intestinal microbiota, and knowledge and practice of the first 1000 days. The data analysis was descriptive and analytical with a significance threshold $\mathrm{p} \leq 0.05$. Results: Out of 224 active agents, 76 (30 men, 46 women) participated in the survey, i.e. $33.9 \%$. The respondent came from the gynecology-obstetrics (54\%) and pediatrics $(46 \%)$ departments and had professional experience $>5$ years in $38 \%$. Thirty-eight percent of the respondents had a good knowledge of the intestinal microbiota. Concerning the first 1000 days of life, $64.5 \%$ of the res- 
Copyright (C) 2021 by author(s) and Scientific Research Publishing Inc. This work is licensed under the Creative Commons Attribution International License (CC BY 4.0).

http://creativecommons.org/licenses/by/4.0/ pondents had a good knowledge of the first 1000 days overall. They advised exclusive breastfeeding for up to 6 months in $95 \%$ of cases. When breastfeeding was not feasible, the main criterion for choosing the infant formula was the composition (57.1\%). They proposed a standard infant formula (43\%), enriched with prebiotic (29.4\%), enriched with probiotic (21.6\%), a symbiotic $(6 \%)$. Good knowledge of the intestinal microbiota was associated with belonging to the paediatric service $(\mathrm{p}=0.013)$, socio-professional category $(\mathrm{p}=$ $0.031)$, year of experience $>5$ years $(p=0.032)$ and the first 1000 days of life to year of experience $>5$ years $(\mathrm{p}<0.01)$. Conclusion: The health personnel interviewed did not have a good knowledge of the intestinal microbiota and the first 1000 days. Capacity building is needed.

\section{Keywords}

Intestinal Microbiota, First 1000 Days, Staff, Knowledge, Côte d'Ivoire

\section{Introduction}

In 2018, 149 million children under five years of age worldwide were stunted, 49 million were wasted, 40 million were overweight or obese, and 340 million suffered from micronutrient deficiencies [1]. In Côte d'Ivoire, the prevalence of stunting and wasting was $21.6 \%$ and $6 \%$, respectively, in 2016 [2]. The triple burden of malnutrition-undernutrition, hidden hunger and overweight-is seriously detrimental to children's growth and development. It exposes children to chronic non-communicable diseases in adulthood, the leading cause of death worldwide [3]. In line with the Global Strategy for Infant and Young Child Feeding, the first 1000 days of life, from conception to two years of age, is now recognized as a "critical period" for promoting healthy growth, health and behavioral, emotional and cognitive development [3] [4] [5] [6]. At the center of this issue is the intestinal microbiota. This microbiota is today considered as an organ in its own right, modulated by nutrition and contributing to the proper development of the child's staturo-weight, psychomotor, and immune systems [7]-[12]. In view of these observations, the Ivorian government has made nutrition one of its priorities. It has adopted a National Multisectoral Nutrition Plan 2016-2020, the first priority of which is to promote and support good nutritional practices and preventive measures against malnutrition. These include exclusive breastfeeding up to 6 months, diversification at 6 months, complete weaning at 2 years and the use of infant formula enriched with prebiotics and probiotics [2]. It is currently observed that, despite government awareness and increasingly precise scientific knowledge of the first 1000 days of life and of the intestinal microbiota, there is a real gap between recommendations and the nutritional management of children in practice. Is non-compliance with these recommendations by parents due to a lack of knowledge and practice of health personnel regarding the intestinal microbiota and the first 1000 days of life? The objective of the work was to assess 
the level of knowledge and practice of health personnel related to the intestinal microbiota and the first 1000 days of life at the University Hospital Center of Bouaké (Côte d'Ivoire) for the improvement of child health.

\section{Methods}

This is a prospective, cross-sectional, descriptive and analytical study carried out in the pediatric and gynecology-obstetrics departments of Bouaké University Hospital, the only tertiary level services located more than $370 \mathrm{~km}$ from Abidjan, the economic capital of the South. The pediatrics department occupies a pavilion-type building located in the northern part of the hospital. It has a capacity of 54 beds. The human resources of this service include 84 agents carrying out care, teaching and research activities. The Gynecology-Obstetrics Department occupies a two-storey building. It is located in the southern part of Bouaké University Hospital and has a staff of 139 agents. The study took place from 01 to 31 July 2017. It focused on health personnel actively involved in the nutritional care of children in the pediatric and gynecology-obstetrics departments of Bouaké University Hospital, including gynecologists, obstetricians, pediatricians, doctors enrolled in specialized studies in pediatrics or gynecology and obstetrics, hospital interns, students in the process of completing their thesis, midwives and nurses. Included in the study were consenting staff recognized by the Human Resources Department of the CHU de Bouaké, working in the gynecological-obstetrics or pediatrics department and present at the time of the survey. Agents who were absent at the time of the survey or who refused to participate in the study were not included in the study. The sampling was exhaustive, taking into account all personnel meeting our selection criteria during the study period. All information about the research, its objectives, the methodology adopted, and the fate of the study results was explained to participants. For the data collection a questionnaire for individual interviews was designed (Annex: Survey form). The validation of the questionnaire passed through several steps. It was first of all a qualitative external validation by submitting the questionnaire to the Regional Health Direction of Gbêkê. During this step we obtained an investigation authorization. Then, we carried out a pre-test on a small number of health workers having the same chararcteristics as those of the study in an urban health center located in the same city. This pre-test enabled us to assess the correct understanding by the health personal and the relevance of the questionnaire. Finally, we carried out an internal validation by submitting the questionnaire to the Medical and Scientific Direction of Bouaké UTH to obtain an investigation authorization. This questionnaire provided information on the socio-professional characteristics of the active staff, their knowledge of the intestinal microbiota, the concept of the first 1000 days of life and their practices in terms of infant nutrition. The data were collected using a structured, anonymous and validated questionnaire, and then digitally coded to allow their exploitation on a microcomputer. The data were entered on the statistical software package EPI info 7. The analysis was descriptive 
and consisted of calculating numbers and determining averages and proportions. For each question, criteria of good or poor knowledge were determined in order to judge the level of knowledge of each participant. Quantitative variables were analyzed as means with standard deviation. Qualitative variables were expressed as proportions. The quantitative variables were compared at the significance level $\mathrm{p} \leq 0.05$. For each variable analyzed the performance threshold was set at $85 \%$ [13]. Knowledge was considered good when over $85 \%$ of correct answers, medium between $84 \%$ and $50 \%$ of correct answers, bad when less than $50 \%$ of correct answers. Participation in the study was free. Participants gave their verbal agreement after explanations about the study. In addition, prior authorization was obtained from the Scientific Medical Department of the Bouake University Hospital with amplification to the heads of the departments concerned before conducting the study. The information collected as part of this survey was made strictly confidential and anonymous through a coding system.

\section{Results}

\subsection{Socio-Professional Characteristics}

Out of a total of 224 active health workers in the two services, 76 participated in the study, a participation rate of $33.9 \%$. Thirty-five participants came from the pediatric service and 41 from the gynecology-obstetrics service. The participant was female in 46 cases and male in 30 cases, for a sex ratio (M/F) of 0.6. The average age was 36 years with extremes of 26 and 58 years. The respondents' work experience was less than 5 years in $61.8 \%$ of cases. The socio-demographic characteristics of participants are shown in Table 1.

\subsection{Knowledge of the Intestinal Microbiota}

Fifty-two (68.4\%) out of 76 health care workers said they had heard of the intestinal microbiota. The remaining 24 (31.6\%) had never heard of the intestinal microbiota. The source of information for those who had heard of the intestinal microbiota was postgraduate education $50 \%(26 / 52)$, basic training $29 \%(15 / 52)$, collaborators $9.6 \%$ (5/52), medical sales representatives $7.6 \%$ (4/52) and on-call debriefings or staff meetings $3.8 \%$ (2/52). Of the 76 respondents, 14 (18.4\%) knew that the intestinal microbiota is composed of bacteria, fungi, parasites and viruses. The other $62(81.6 \%)$ gave a false answer. The distribution of microorganisms along the digestive tract from the oral cavity to the colon was known by 10 respondents (13.2\%) and unknown by the other 66 (86.8\%). The respondents stated that the intestinal microbiota had a beneficial role in the body in 61 cases $(82.2 \%)$. However, the beneficial role of the intestinal microbiota, i.e. involvement in digestion, maturation of the immune system, metabolic reactions, and prevention of diseases was known by only 6 respondents (8\%). The period from pregnancy to 3 years during which the microbiota sets up and develops was known by 3 respondents (4\%) and unknown by the other 73 respondents (96\%). The influence of the delivery route on the establishment of the intestinal micro- 
biota was known by 27 respondents (35.5\%) and unknown by the other 49 respondents $(64.5 \%)$. The influence of age on the composition of the intestinal microbiota was known by 42 respondents (55.3\%) and unknown by the other 34 respondents (44.7\%). The respondents knew the definition of probiotic in $43.2 \%$ of cases and did not know the definition of prebiotic in $100 \%$ of cases. However, $46 \%$ of the respondents stated that prebiotics and probiotics had a beneficial effect on the intestinal microbiota. Overall, 29\% (22/76) of the staff surveyed had a good knowledge of the intestinal microbiota. Good knowledge of the intestinal microbiota was associated with belonging to the paediatric service $(p=0.013)$, socio-professional category $(\mathrm{p}=0.031)$, year of experience $>5$ years $(\mathrm{p}=0.032)$ (Table 2).

Table 1. Characteristics of the study population.

\begin{tabular}{|c|c|c|}
\hline Variables & Numbers $(\mathrm{n} / \mathrm{N})$ & Percentage \\
\hline \multicolumn{3}{|l|}{ Socio-professional categories } \\
\hline - Midwives and Nurses & $40 / 76$ & 52.6 \\
\hline - Doctor DES & $24 / 76$ & 31.6 \\
\hline - Internal & $5 / 76$ & 6.6 \\
\hline - Assistant & $3 / 76$ & 4.6 \\
\hline - Doctoral students & $3 / 76$ & 4.6 \\
\hline \multicolumn{3}{|c|}{ Year of the Diploma of Specialized Studies } \\
\hline - $1^{\text {st }}$ Year & $6 / 23$ & 26 \\
\hline - $2^{\text {nd }}$ Year & $6 / 23$ & 26 \\
\hline - $3^{\text {rd }}$ Year & $9 / 23$ & 39 \\
\hline - $4^{\text {th }}$ Year and dissertation & $2 / 23$ & 9 \\
\hline \multicolumn{3}{|l|}{ Age group in years } \\
\hline - $25-30$ & $16 / 76$ & 21 \\
\hline - $31-35$ & $26 / 76$ & 34.2 \\
\hline - $36-40$ & $17 / 76$ & 22.4 \\
\hline - $>40$ & $17 / 76$ & 22.4 \\
\hline \multicolumn{3}{|l|}{ Work experience in years } \\
\hline - $1-5$ & $47 / 76$ & 61.8 \\
\hline - $6-10$ & $17 / 76$ & 22.3 \\
\hline - $11-15$ & $6 / 76$ & 7.9 \\
\hline - $16-20$ & $3 / 76$ & 4 \\
\hline - $>20$ & $3 / 76$ & 4 \\
\hline
\end{tabular}


Table 2. Factors associated with knowledge of the intestinal microbiota.

\begin{tabular}{|c|c|c|c|c|}
\hline \multirow{2}{*}{ Variables } & \multicolumn{2}{|c|}{ Level of knowledge } & \multirow{2}{*}{ Odds ratio } & \multirow{2}{*}{$\mathbf{P}$} \\
\hline & Good & Insufficient & & \\
\hline \multicolumn{5}{|l|}{ Sex } \\
\hline - Male & 10 & 20 & \multirow{3}{*}{$1.42[0.52-3.9]$} & \multirow{3}{*}{0.49} \\
\hline & & & & \\
\hline - Female & 12 & 34 & & \\
\hline \multicolumn{5}{|l|}{ Service } \\
\hline - Pediatrics & 15 & 20 & \multirow{3}{*}{$3.6[1.27-10.4]$} & \multirow{3}{*}{$0.013^{*}$} \\
\hline & & & & \\
\hline - Gynecology and Obstetrics & 7 & 34 & & \\
\hline \multicolumn{5}{|l|}{ Unit } \\
\hline - Delivery room & 8 & 19 & \multirow{5}{*}{$0.94[0.3-2.92]$} & \multirow{5}{*}{0.88} \\
\hline - Hospitalization & 6 & 16 & & \\
\hline - Emergencies & 3 & 10 & & \\
\hline - Neonatology & 4 & 9 & & \\
\hline - Prenatal consultation & 1 & 0 & & \\
\hline \multicolumn{3}{|l|}{ Socio-professional categories } & \multirow{4}{*}{$0.26[0.07-0.89]$} & \multirow{4}{*}{$0.031^{*}$} \\
\hline - Medical & 15 & 21 & & \\
\hline & & & & \\
\hline - Medical Para & 7 & 33 & & \\
\hline \multicolumn{5}{|l|}{ Year of experience } \\
\hline - $\leq 5$ years & 9 & 38 & \multirow{3}{*}{$0.29[0.1-0.87]$} & \multirow{3}{*}{$0.032^{\star}$} \\
\hline & & & & \\
\hline - $>5$ years & 13 & 16 & & \\
\hline
\end{tabular}

*Significant at the $5 \%$ threshold.

\subsection{Knowledge of the First 1000 Days of Life}

For the first 1000 days of life, the respondent said it was the period from conception to age 2 (45\%), birth to 2 years (33\%), 2 to 4 years (5\%), and conception to birth (3\%). Fourteen percent of the agents did not know which period they were in. For the respondents, the first 1000 days constituted a window of opportunity and a sensitive period in the child's development (75\%), a period during which the child should be seen regularly in hospital (4\%). Regarding their knowledge of the impact of a good management of the first 1000 days on child development, the respondents answered that it contributes to the good staturo-weight and psychomotor development of the child (62\%), to the prevention of metabolic diseases in adulthood (3\%), and to the avoidance of diarrheal diseases (1.5\%). For the agent interviewed, good maternal nutrition combined with appropriate breastfeeding or breast-milk substitutes and prevention of malnutrition (68.4\%) contributed to good management of the first 1000 days. The health worker did 
not know what good management of this period entailed or gave an incomplete answer in $16 \%$ and $21 \%$ respectively. Overall, $64.5 \%$ of the respondents had a good knowledge of the first 1000 days. Good knowledge of the first 1000 days of life was associated with year of experience $>5$ years $(\mathrm{p}<0.01)($ Table 3$)$.

\subsection{Attitude and Practice of Health Care Staff}

Regarding the WHO recommendations related to infant feeding modalities, respondents cited only exclusive breastfeeding from 0 to 6 months (15.8\%), exclusive breastfeeding from 0 to 6 months and then diversification (61.8\%). They had no response in $22.4 \%$ of cases. Exclusive breastfeeding was the feeding choice for infants from 0 to 6 months of age for $95 \%$ of respondents. Respondents prescribed or recommended infant formula in their practice in $67 \%$ of cases. These were standard infant formulas in $43 \%$ of cases, and milk enriched with prebiotics in $29.4 \%$ of cases. The main criteria for the choice of milk substitute by the respondents were the composition of the milk (57.1\%), the return after prescription (11.7\%) and the brand of milk (3.8\%).

Table 3. Factors associated with knowledge of the first 1000 days of life.

\begin{tabular}{|c|c|c|c|c|}
\hline \multirow{2}{*}{ Variables } & \multicolumn{2}{|c|}{ Level of knowledge } & \multirow{2}{*}{ Odds ratio } & \multirow{2}{*}{$\mathbf{P}$} \\
\hline & Good & Insufficient & & \\
\hline \multicolumn{5}{|l|}{ Sex } \\
\hline - Male & 18 & 12 & \multirow{3}{*}{$0.72[0.28-1.88]$} & \multirow{3}{*}{0.49} \\
\hline & & & & \\
\hline - Female & 31 & 15 & & \\
\hline \multicolumn{5}{|l|}{ Service } \\
\hline - Pediatrics & 22 & 13 & \multirow{3}{*}{$0.88[0.34-2.25]$} & \multirow{3}{*}{0.78} \\
\hline & & & & \\
\hline - Gynecology and Obstetrics & 27 & 14 & & \\
\hline \multicolumn{5}{|l|}{ Unit } \\
\hline - Delivery room & 18 & 9 & \multirow{5}{*}{$0.89[0.3-2.56]$} & \multirow{5}{*}{0.99} \\
\hline - Hospitalization & 11 & 11 & & \\
\hline - Emergencies & 7 & 6 & & \\
\hline - Neonatology & 12 & 1 & & \\
\hline - Prenatal consultation & 1 & 0 & & \\
\hline \multicolumn{5}{|l|}{ Socio-professional categories } \\
\hline - Medical & 26 & 9 & \multirow{3}{*}{$0.44[0.16-1.23]$} & \multirow{3}{*}{0.19} \\
\hline & & & & \\
\hline - Medical Para & 23 & 17 & & \\
\hline \multicolumn{5}{|l|}{ Year of experience } \\
\hline - $\leq 5$ years & 21 & 26 & \multirow{3}{*}{$0.03[0.001-0.18]$} & \multirow{3}{*}{$<0.01^{\star}$} \\
\hline & & & & \\
\hline - $>5$ years & 28 & 1 & & \\
\hline
\end{tabular}

*Significant at the $5 \%$ threshold. 


\section{Discussion}

This prospective cross-sectional descriptive and analytical study conducted at the Bouake University Hospital in the gynecology-obstetrics and pediatrics departments aims to evaluate the knowledge and practices of health care personnel regarding the intestinal microbiota and the first 1000 days of life. The study shows that the health personnel interviewed had insufficient knowledge of the intestinal microbiota and the concept of the first 1000 days of life with a negative impact on their practice. These results must be qualified because this is a monocentric hospital study carried out over a short period of time in the only tertiary level reference hospital in the central and northern regions of Côte d'Ivoire. The individual interview method used to conduct the survey exposes to memory bias and also gives the respondent the opportunity to communicate or suggest answers to the colleague not yet surveyed. To circumvent this risk, the interviewer asked the participant at the end of the interview not to communicate these responses to other study participants. Despite methodological limitations, the study elicits the following discussion points regarding the socio-professional characteristics, knowledge, attitudes, and practices of health care workers related to the intestinal microbiota and the concept of the first 1000 days.

\subsection{At the Level of Socio-Professional Characteristics}

The present study shows that the participants are men in 30 cases and women in 46 cases with an average age of 36 years and no more than 5 years of work experience in $61.8 \%$ of cases. These results are similar to those reported by Asse et al. [14] in 2018 in the same services with a predominance of women (sex ratio $(\mathrm{M} / \mathrm{F})=0.8)$, an average age of 36 years and less than 5 years of work experience in $64.3 \%$ of cases. In this work the overall participation rate in the study is $33.9 \%$. This rate is lower than the $54.4 \%$ reported by Asse et al. [14] in the same services in 2018. This low participation rate could be explained by the fact that staff are not used to this type of study. Some agents certainly do not perceive the interest of such a study for their practice. Other agents feel that the workload is too heavy and does not give them the time needed to answer the questions.

\subsection{Concerning the Knowledge of the Intestinal Microbiota}

The study reveals that only $29 \%$ of the respondents have a good knowledge of the intestinal microbiota. This is insufficient. The insufficiency mainly concerns the nature of the microorganisms composing the microbiota, their number and distribution in the digestive tract as well as the role of the intestinal microbiota and the consequences of dysbiosis. According to the data in the literature, the intestinal microbiota contains 100,000 billion bacteria, i.e. ten times more than the number of cells making up the human body [15] [16]. Weighing two kilograms, more than the weight of the brain, it contains more than 2000 bacterial species. In addition, the number of genes in the microbiota is at least 200 times greater than that of the human genome. Bacterial density varies according to the 
area of the digestive tract. It increases throughout the digestive tract with the exception of the oral cavity where bacteria are numerous in quantity and quality [15]. In the study alone, $6 \%$ of the staff surveyed were aware of the beneficial functions of the intestinal microbiota in the body, although more than threequarters of them claimed that it has a beneficial role in the body. Indeed, the intestinal microbiota maintains a symbiotic relationship with the intestinal mucosa and confers substantial metabolic, immunological and intestinal protective functions to the healthy individual. It constitutes an organ in itself endowed with a great functional plasticity and a great metabolic capacity. [17]. At the metabolic level, the microbiota plays a major role in the fermentation of dietary carbohydrates that have escaped proximal digestion leading to the synthesis of shortchain fatty acids such as butyrate, propionate and acetate, which are a source of energy for the host [18]. It has also been shown that the intestinal microbiota has a positive effect on lipid metabolism by suppressing the inhibition of lipoprotein lipase activity in adipocytes [19]. The synthesis of vitamin $\mathrm{K}$ and several components of vitamin B is another major metabolic function of the intestinal microbiota. It also plays an important role in intestinal immunomodulation [20] [21]. Only $23.3 \%$ of the participants have a good knowledge of the factors that influence the intestinal microbiota. Indeed, the composition of the microbiota diversifies according to several factors, in particular the intrauterine environment and the term of pregnancy [22]. In addition, the mode of delivery is a major modulating factor of the intestinal microbiota [23] [24]. Indeed, it has clinical consequences such as an increase in the number of infections, allergies, but also an increase in type 1 diabetes or obesity [25]. Another factor is diet. The microbiota that establishes itself in the breastfed newborn has a greater diversity than that of the newborn fed with artificial milk. The mother's milk promotes the implantation of Bifidobacteria. However, the intestinal microbiota and its human host live in symbiosis and the microbiota is able to regulate, in the host, the expression of certain genes associated with the immune system [26]. Numerous publications have also noted the disruption of the intestinal microbiota by drugs such as antibiotics and proton pump inhibitors [27] [28] [29] [30]. The low level of knowledge of the intestinal microbiota in the study could be explained by the fact that almost three-quarters of the respondents were not aware of this concept during basic training. Above all, the study reveals that the respondents' source of information is dominated by postgraduate education, experience sharing among collaborators, medical sales representatives and on-call debriefing meetings. Factors significantly associated with a good knowledge of the intestinal microbiota are membership of the pediatrics department, the socio-professional category of physician and the number of years of service in excess of 5 years. Compared to the gynecology and obstetrics department, membership in the pediatrics department of Bouaké University Hospital was 3.6 times associated with good knowledge of the intestinal microbiota. This can be explained by the fact that the majority of the pediatric staff participated in the scientific 
days organized by the Ivorian Pediatric Society on the theme of infant nutrition. The same staff regularly participates in capacity building sessions on child nutrition in the pediatric ward. The fact that doctors have a better knowledge of the intestinal microbiota than caregivers can be explained by the fact that most of these doctors are enrolled in special pediatrics diplomas and regularly participate in postgraduate courses on the theme of the intestinal microbiota. A year of experience of 5 years or more is also associated with a good knowledge of the intestinal microbiota. The notion of the intestinal microbiota seems new in our context and is not part of the basic medical and paramedical training curriculum. Thus, newly graduated health workers or those who have not yet completed their training do not seem to have acquired sufficient knowledge on this subject.

\subsection{Knowledge of the First 1000 Days}

The study shows that only $64.5 \%$ of the participants have a good knowledge of the first 1000 days of life. This is also insufficient. The lack of knowledge mainly concerns the period corresponding to the first 1000 days of life and its importance. In fact, one participant out of two does not know the corresponding period and one out of four did not know that this stage of life constitutes a window of opportunity whose good management has a positive impact on health in adulthood. Indeed, the concept "first 1000 days of life" refers to the period from conception until the child is two years old. This is a period of priority interest, during which the environment of the pregnant woman and then of the baby plays a very important role in the construction of her future health capital. However, what are the benefits of good nutrition during the first 1000 days of life? For the respondents a good digestion during the first 1000 days of life, promotes a good staturo-weight and psychomotor development $(48.7 \%)$, prevents metabolic diseases in adulthood (2.6\%) and avoids diarrheal diseases (1.3\%). In a study carried out in Lumbubashi, Congo, by Shongo et al. [31] nearly 70\% of respondents believed that there was a link between low birth weight and future growth. The work of Ehrenkranz et al. [32] tends to confirm this observation. Roseboon et al. [33] in the Netherlands observed that children who experienced nutritional restriction during their intrauterine life developed a greater susceptibility to type 2 diabetes, obesity, hypertension and cardiovascular disease in adulthood. The year of experience greater than or equal to 5 years is associated with good knowledge of the concept of the first 1000 days of life in the study. This could be explained by the fact that the acquisition of good knowledge of the first 1000 days of life takes place after several years of medical practice, since this concept is not included in the basic training curriculum for healthcare personnel.

\subsection{In Terms of the Attitudes and Practices of the Staff Surveyed}

In this work, $100 \%$ of the respondents had insufficient knowledge of the WHO recommendations related to infant feeding. Twelve respondents (15.8\%) cited only exclusive breastfeeding from 0 to 6 months, 47 (61.8\%) spoke of diversifica- 
tion and 17 (22.4\%) gave no answer. Indeed, the WHO has issued recommendations related to infant and child feeding [34]. These included promoting exclusive breastfeeding for the first 6 months of life, starting diversification or complementary feeding from 6 months of age while continuing breastfeeding until the age of 2 years, introducing family feeding from 1 year of age, achieving complete weaning at least at 2 years of age, and encouraging the improvement and promotion of good nutrition for pregnant and breastfeeding women. In this study, $95 \%$ of the participants followed these recommendations. On the other hand, $67 \%$ of the respondents prescribe or recommend infant formula in their practice. These were standard milk in $43 \%$, milk enriched with prebiotics only $(29.4 \%)$ or enriched with probiotics only (21.6\%). The criteria for choosing one type of milk over another was dominated by milk composition (57.1\%), return after prescription (11.7\%) and milk brand (3.8\%). Beyond these criteria, it would be interesting for practitioners to take into account the birth term, the age of the child and the socio-economic conditions of the parents. In the study by Shongo et al. [31], for a little more than half of the respondents (52.5\%), the good period for dietary diversification is from 6 months onwards. For 10\%, this period was between 4 and 6 months.

\section{Conclusion}

This study clearly shows that the current state of knowledge of health workers on the intestinal microbiota, the first 1000 days of life and the WHO nutrition recommendations is insufficient. This inadequacy is an obstacle to the adequate nutritional management of young infants and the correct sensitization of parents on infant nutrition. To improve the situation, we recommend the reinforcement of health staff capacities on the intestinal microbiota and the concept of the first 1000 days of life as well as the integration of these new concepts in the basic training curriculum of health staff in Côte d'Ivoire.

\section{Acknowledgements}

Our sincere thanks to all the staff of the pediatric and gynecology-obstetrics departments.

\section{Authors' Contribution}

All authors participated, read and approved the final manuscript.

\section{Conflicts of Interest}

The authors declare no conflicts of interest regarding the publication of this paper.

\section{References}

[1] United Nations International Children's Emergency Fund (2020) The State of the World's Children 2019: Children, Food and Nutrition: Growing up Well in a 
Changing World. United Nations International Children's Emergency Fund, New York.

[2] Ministry of Health and Public Hygiene (2016) National Multisectoral Nutrition Plan 2016-2020 (RCI). Ministry of Health and Public Hygiene, Abidjan.

http://www.nutrition.gouv.ci/fichier/doc/PNMN $2016 \quad 2020 \quad 15 \quad 08$ 16.pdf

[3] Hercberg, S. (2013) Proposal for a New Impetus for French Public Health Nutrition Policy in the Framework of the 2014 National Health Strategy. http://www.ladocumentationfrancaise.fr/var/storage/rapports-publics/144000068.pdf

[4] United Nations International Children's Emergency Fund (2003) Improving Child Nutrition: The Achievable Imperative for Global Progress. UNICEF, New York, $124 \mathrm{p}$. https://data.unicef.org/resources/improving-child-nutrition-the-achievable-imperat ive-for-global-progress/nutritionreport april2013 final 29/

[5] United Nations International Children's Emergency Fund (2016) State of the World's Children 2016.

https://www.unicef.org/french/publications/files/UNICEF SOWC 2016 French L AST.pdf

[6] United Nations Standing Committee on Nutrition (2006) Report of the Standing Committee on Nutrition at its Thirty-Third Session http://www.unscn.org/files/Annual Sessions/33rd SCN Session/33rd session REP ORT.pdf

[7] Simon, J. (2016) The Intestinal Microbiota: A Little-Known Organ. Thesis Med, Univ Rennes 1 .

https://ecm.univ-rennes1.fr/nuxeo/site/esupversions/5aa48d26-f430-4bdd-b537-8bd 52d6f0530?inline

[8] Morin, S. (2012) Influence of the Presence and Composition of the Intestinal Microbiota on the Development and Prevention of Food Allergies. Thesis Med, Université René Descartes-Paris V, Paris. https://tel.archives-ouvertes.fr/tel-00772775/document

[9] Tap, J. (2009) Impact du régime alimentaire sur la dynamique structurale et fonctionnelle du microbiote intestinal humain. Thesis Med, Pierre and Marie Curie University, Paris. https://hal.inrae.fr/tel-02824828/document

[10] Conlon, M.A. and Bird, A.R. (2015) The Impact of Diet and Lifestyle on Gut Microbiota and Human Health. Nutrients, 7, 17-44. https://doi.org/10.3390/nu7010017

[11] Mu, C.L., Yang, Y.X. and Zhu, W.Y. (2016) Gut Microbiota: The Brain Peacekeeper. Frontiers in Microbiology, 7, 345. https://doi.org/10.3389/fmicb.2016.00345

[12] Brahe, L.K., Astrup, A. and Larsen, L.H. (2016) Can We Prevent Obesity-Related Metabolic Diseases by Dietary Modulation of the Gut Microbiota? Advances in Nutrition, 7, 90-101. https://doi.org/10.3945/an.115.010587

[13] Essi, M.J. and Njoya, O. (2013) L'enquête CAP (Connaissances, Attitudes et Pratiques) en recherche médicale. Health Sciences and Disease, 14, 1-3. http://www.hsd-fmsb.org/index.php/hsd/article/viewFile/183/pdf 22

[14] Asse, K.V., Azagoh-Kouadio, R., Yao, K.C., Aka-Tanoh, K.A., Avi, C., Yeboua, K.R., et al. (2018) Violence on Health Professionals: Experience of the Obstetrics \& Gynecology and Pediatrics Departments at the University Teaching Hospital of Bouaké, Côte d'Ivoire. Open Journal of Pediatrics, 8, 8-18. https://doi.org/10.4236/ojped.2018.81002

[15] Arrieta, M.C., Stiemsma, L.T., Amenyogbe, N., Brown, E.M. and Finlay, B. (2014) The Intestinal Microbiome in Early Life Health and Disease. Frontiers in Immunology, 5, 427. https://doi.org/10.3389/fimmu.2014.00427 
[16] Saavedra, J.M. and Datillo, A.M. (2012) Early Development of Intestinal Microbiota; Implications for Future Health. Gastroenterology Clinics of North America, 41, 717-731. https://doi.org/10.1016/j.gtc.2012.08.001

[17] Sonnenburg, J.L., Xu, J., Leip, D.D., Chen, C.H., Westover, B.P., Weatherford, J., et al. (2005) Glycan Foraging in Vivo by a Gut-Adapted Bacterial Symbiont. Science, 307, 1955-1959. https://doi.org/10.1126/science.1109051

[18] Macfarlane, S. and Macfarlane, G.T. (2003) Regulation of the Production of Short Chain Fatty Acids. Proceedings of the Nutrition Society, 62, 67-72. https://doi.org/10.1079/PNS2002207

[19] Hooper, L.V., Wong, M.H., Thelin, A., Hansson, L., Falk, P.G. and Gordon, J.I. (2001) Molecular Analysis of Commensal Host-Microbial Relationships in the Gut. Science, 291, 881-884. https://doi.org/10.1126/science.291.5505.881

[20] Jandhyala, S.M., Talukdar, R., Subramanyam, C., Vuyyuru, H., Sasikala, M. and Nageshwar Reddy, D. (2015) Role of the Normal Gut Microbiota. World Journal of Gastroenterology, 21, 8787-8803. http://dx.doi.org/10.3748/wjg.v21.i29.8787

[21] Schuijt, T.J., Lankelma, J.M., Scicluna, B.P., Melo, F.S., Roelofs, J.J.T.H. and Daan de Boer, J. (2016) The Intestinal Microbiota Plays a Protective Role in Host Defence against Pneumococcal Pneumonia. Gut, 65, 575-583. http://dx.doi.org/10.1136/gutjnl-2015-309728

[22] Guarino, A., Wudy, A., Basile, F., Ruberto, E. and Buccigrossi, V. (2012) Composition and Roles of Intestinal Microbiota in Children. The Journal of Maternal-Fetal \& Neonatal Medicine, 25, 63-66. https://doi.org/10.3109/14767058.2012.663231

[23] Huurre, A., Kalliomäki, M., Rautava, S., Rinne, M., Salminen, S. and Isolauri E. (2008) Mode of Delivery Effects on Gut Microbiota and Humoral Immunity. Neonatology, 93, 236-240. https://doi.org/10.1159/000111102

[24] Underwood, M.A., German, J.B., Lebrilla, C.B. and Mills, D.A. (2015) Bifidobacterium longum Subspecies Infantis: Champion Colonizer of the Infant Gut. Pediatric Research, 77, 229-235. https://doi.org/10.1038/pr.2014.156

[25] Cardwell, C.R., Stene, L.C., Joner, G., Svensson, J., Goldacre, M.J., Parslow, R.C., et al. (2008) Caesarean Section Is Associated with an Increased Risk of ChildhoodOnset Type 1 Diabetes Mellitus: A Meta-Analysis of Observational Studies. Diabetologia, 51, 726-735. https://doi.org/10.1007/s00125-008-0941-Z

[26] Schwartz, S., Friedberg, I., Ivanov, I.V., Davidson, L.A., Goldsby, J.S., Dahi, D.B., et al. (2012) A Metagenomic Study of Diet-Dependant Interaction between Gut Microbiota and Host in Infants Reveals Differences in Immune Response. Genome Biology, 13, Article No. r32. https://doi.org/10.1186/gb-2012-13-4-r32

[27] Canani, R.B., Cirillo, P., Roggero, P., Romano, C., Malamisura, B., Terrin, G., et al. (2006) Therapy with Gastric Acidity Inhibitors Increases the Risk of Acute Gastroenteritis and Community-Acquired Pneumonia in Children. Pediatrics, 117, e817e820. https://doi.org/10.1542/peds.2005-1655

[28] Hildebrand, H., Malmborg, P., Askling, J., Ekbom, A. and Montgomery, S.M. (2008) Early-Life Exposures Associated with Antibiotic Use and Risk of Subsequent Crohn's Desease. Scandinavian Journal of Gastroenterology, 43, 961-966. https://doi.org/10.1080/00365520801971736

[29] Shaw, S.Y., Blanchard, J.F. and Bernstein, C.N. (2010) Association between the Use of Antibiotics in the First Year of Life and Pediatric Inflammatory Bowel Disease. American Journal of Gastroenterology, 105, 2687-2692.

https://doi.org/10.1038/ajg.2010.398 
[30] Hviid, A., Svanström, H. and Frisch, M. (2011) Antibiotics Use and Inflammatory Bowel Diseases in Childhood. Gut, 60, 49-54. http://dx.doi.org/10.1136/gut.2010.219683

[31] Shongo ya, P.M., Kasole, L.T., Kantenga, W.G., Ngweja, T.D., Luboya, N.O. and Wembonyama, O.S. (2017) Knowledge, Attitude and Practice of the Medical Staff on the First 1000 Days of Life, Case of the City of Lubumbashi. 8th Congress of the Pediatric Society of Democratic Congo, Kinshasa, 23-24 October 2017.

[32] Ehrenkranz, R.A., Dusick, A.M., Vohr, B.R., Wright, L.L., Wrage, L.A., Kenneth Poole, W., et al. (2006) Growth in the Neonatal Intensive Care Unit Influences Neurodevelopmental and Growth Outcomes of Extremely Low Birth Weight Infants. Pediatrics, 117, 1253-1261. https://doi.org/10.1542/peds.2005-1368

[33] Roseboom, T. and Susanne de Rooij, R.P. (2006) The Dutch Famine and Its LongTerm Consequences for Adult Health. Early Human Development, 82, 485-491. https://doi.org/10.1016/j.earlhumdev.2006.07.001

[34] World Health Organization (2002) Infant and Young Child Nutrition: A Global Strategy for Infant and Young Child Feeding. Report of the Secretariat. http://apps.who.int/gb/archive/pdf files/WHA55/fa5515.pdf?ua=1\&ua=1 


\section{Annex: Survey Form}

Knowledge, attitudes and practices of the health personnel of the pediatric and gynecology-obstetrics departments of the Bouaké University Hospital Center $(\mathrm{CHU})$ regarding the intestinal microbiota and the first 1000 days of life

Registration number:

Date of registration:

1) Identity

- Age:............years Sex: Male $\square$ Female $\square$

- Service: Pediatrics $\square$ Gynecology-Obstetrics $\square$

- Units: $\quad$ Neonatalogy $\square$ Delivery room $\square$ Hospitalisation $\square$ Emergency

- Socioprofessional category: Assistant $\square$ physician in pediatrics specialty $\square$ Internship $\square$ Nurse $\square$ Midwive $\square$ Nurse's assistant $\square$ Thesis student $\square$ If physician in speciality, specify year: $1^{\text {st }}$ year $\square 2^{\text {nd }}$ year $\square 3^{\text {rd }}$ year $\square$ $4^{\text {th }}$ year $\square$ Thesis $\square$

Professional experience:. years

2) Knowledge of the intestinal microbiota

- Have you ever heard of the intestinal microbiota? Yes $\square \mathrm{No} \square$ If Yes, under what circumstances? During the years of training Postgraduate teaching $\square$ Staff $\square$ Medical visitor $\square$ Collaborator $\square$

- What is the intestinal microbiota composed of? Bacteria $\square$ Virus Parasite $\square$ Fungus $\square$ All at once $\square$ Don't know

- In which part of the digestive tract is the intestinal microbiota colonized? Oral cavity $\square$ Stomach $\square$ Small intestine $\square$ Colon $\square$ All at once Don't know

- What is the approximate number of microorganisms colonizing the intestinal microbiota? 100,000 $\square$ 1,000,000 $\square$ 100,000 milliards $\square$ Don't know $\square$

- Does the intestinal microbiota play a beneficial role in our body? Yes $\square$ No $\square$

- What role does the intestinal microbiota play in the body? Involvement in digestion Involvement in the maturation of the immune System Involvement in many metabolic pathways $\square$ Involvement in many diseases $\square$ Don't know $\square$

- At what point in life does the intestinal microbiota develop? Pregnancy $\square$ Chilbirth $\square 0$ to 6 months $\square 6$ to 12 months 1 to 3 years $\square$ After 3 years $\square$ Adult age $\square$ Don't know

- Is the intestinal microbiota of a child born by the lower route richer than that of a newborn born by caesarean section? Yes $\square \mathrm{No} \square$

- Does the composition of the intestinal microbiota vary with age? Yes $\square$ No $\square$

- What factors influence the development of the intestinal microbiota? Genetics $\square$ Pregnancy $\square$ Route of delivery $\square$ Breastfeeding $\square$ 
Infant formula $\square$ Antibiotic $\square$ Infection $\square$ All at once $\square$ Don't know $\square$

- What is a prebiotic? Pathogenic microorganism

Non-pathogenic microorganisms $\square$ Digestible ingredients $\square$

Non-digestible ingredients $\square$ Don't know

- What is a probiotic? Pathogenic microorganism

Non-pathogenic microorganisms $\square$ Digestible ingredients

Non-digestible ingredients $\square$ Don't know $\square$

- What is the impact of prebiotics and probiotics on the intestinal microbiota?

Favorable $\square$ Unfavorable $\square$ None $\square$ Don't know

3) Knowledge about the first 1000 days

- What period of life corresponds to the first 1000 days?

From conception to birth $\square$ From birth to 2 years $\square$ From 2 to 4 years

From conception to 2 years $\square$ Don't know

- What does the first 1000 days represent? A window of opportunity A sensitive period in the child's development $\square$

$A$ period during which the child needs to be seen regularly in hospital $\square$ A period of rapid growth of the child $\square$ Don't Know

- What is the impact of good management of the first 1000 days on child development?

- What is good management of the first 1000 days?

Good maternal nutrition $\square$ Appropriate breastfeeding or milk substitute $\square$ Prevention of malnutrition $\square$ Raising families' standard of living $\square$

All these actions at once $\square$ Don't Know $\square$

\section{4) Attitude and practice of health care staff}

- What are the WHO recommendations related to infant feeding?

- What is your choice of infant feeding for infants 0 - 6 months? Exclusive breastfeeding $\square$ Formula feeding $\square$ Formula feeding $\square$ Formula replacement $\square$ Mixed feeding $\square$ No preference $\square$

- Do you prescribe or recommend infant formula? Yes $\square$ No $\square$

- What infant formula(s) do you prescribe or advise most?.

- What are your selection criteria? The brand $\square$ The composition The return after prescription $\square$ Service recommendations $\square$ Other $\square$

Thank you for your time. 